\title{
23. Explaining the Results
}

\author{
Antony Green
}

Labor came to office in 2007 with its strongest hold on government in the nation's history - it was, for the first time, in office nationally and in every state and territory. Six years later Labor left national office with its lowest first preference vote in a century. For only the third time since the First World War, a governing party failed to win a third term in office. From a clean sweep of governments in 2007, by mid-2014 Labor's last bastions were minority governments in South Australia and the Australian Capital Territory. ${ }^{1}$

Based on the national two-party-preferred vote, Labor's 2013 result was less disastrous than previous post-war lows in 1966, 1975, 1977 and 1996. Labor also bettered those four elections on the proportion of House seats won. The two-party-preferred swing of 3.6 percentage points was also small for a change of government election, equal to the swing that defeated the Fraser Government in 1983 but smaller than those suffered by Whitlam in 1975, Keating in 1996 and Howard in 2007. Even over two elections from 2007 to 2013, the two-partypreferred swing of 6.2 percentage points was below that suffered by Labor previously over two elections (1961-66 and 1972-75), and smaller than the swing against the Coalition between 1977 and 1983. By the measure of first preference vote share, the 2013 election was a dreadful result for Labor, its lowest vote share since $1904 .^{2}$ Labor's vote share slid from 43.4 per cent in 2007 to 38.0 per cent in 2010 and 33.4 per cent in 2013.

Despite success at the 2013 election, the Liberal and National party coalition was not the major vote beneficiary of Labor's decline. The Coalition's vote share rose from 42.1 per cent in 2007 to 45.6 per cent in 2013 , attracting only a third of the fall in Labor's vote share over two elections. The most notable feature of the 2013 election was the surge in support for third parties and independents, on top of Green support that remained stable over two elections. In both the House and Senate, support for non-major party candidates rose to levels never previously recorded at an Australian national election.

With a disastrous decline in its first preference vote, the Labor Party only remained competitive at the 2010 and 2013 elections through strong preference flows from an enlarged pool of votes from electors who first voted for third

\footnotetext{
1 Unless otherwise noted, the historical comparisons in this chapter have been calculated from the tables of historic federal election results in Barber (2011).

2 The federal Labor Party polled 27.1 per cent of the vote at the 1931 election, but Labor's overall vote that year was 37.7 per cent if the breakaway New South Wales Lang Labor Party is included in the Labor total.
} 
parties and independents. Concentrating on the two-party-preferred result overlooks the long-term impact of a low first preference vote on the Labor Party and the competitiveness of the Australian party system.

\section{State of the House}

The 2013 election was fought on largely unchanged boundaries with only minor redistributions taking place in Victoria and South Australia to bring enrolments back within permitted variation. No electorate changed notional party status based on the new boundaries, and no by-elections were held in the life of the 43rd parliament. Twenty-five House members retired at the 2013 election compared to 20 in 2010 and 21 in 2007. Thirteen Labor and 10 Coalition members retired, as well as the two independents who put the Gillard Government back into office in 2010, Tony Windsor and Rob Oakeshott. Eight of the Coalition's retirees had long careers as backbench members and were older than Labor's oldest retiree, 64-year-old former leader Simon Crean. Of Labor's 13 retirements, nine had been cabinet ministers within the previous 12 months, ${ }^{3}$ a bitter harvest of Labor's leadership battles.

Oakeshott's and Windsor's decisions to retire gifted their seats to the Coalition. Effectively Labor went into the election with 72 seats to the Coalition's 75 . The Coalition needed a net gain of one seat for majority government; Labor needed a net gain of four seats in an electoral climate where polls in several keys states indicated Labor was certain to lose seats.

After the election there were 37 new parliamentarians in the House of Representatives, including two former members returning ${ }^{4}$ and three senators transferring from the other chamber. ${ }^{5}$ Seventeen members were defeated: 14 Labor, one Liberal and the two party members who had moved to the crossbenches, Craig Thomson and Peter Slipper. ${ }^{6}$ The only Liberal member defeated was frontbencher Sophie Mirabella, who lost her Victorian seat of Indi to independent Cathy McGowan. The Liberal Party lost the Queensland seat of Fairfax to Clive Palmer but regained O'Connor from the Nationals.

\footnotetext{
3 The nine were Greg Combet, Simon Crean, Craig Emerson, Martin Ferguson, Peter Garrett, Julia Gillard, Robert McClelland, Nicola Roxon and Stephen Smith.

4 Former Howard Government minister Mal Brough in Fisher and Liberal Jason Wood winning back his seat of La Trobe.

5 Labor's David Feeney and Matt Thistlethwaite and Nationals Deputy Leader Barnaby Joyce, who won Tony Windsor's former seat of New England. Joyce became only the sixth federal member to represent two states, the first in six decades, and the first to do so representing two states in different chambers, having been a Queensland Senator since 2005.

6 Both Thomson and Slipper fell short of the 4 per cent barrier required to recover deposits and receive election funding. Slipper recorded 1.6 per cent, possibly the lowest vote ever for a sitting member. Both members left parliament facing criminal charges.
} 


\section{Parties and candidates}

Political parties have been central to Australian politics since Federation, but it was not until 1984 that parties were registered and party names appeared on ballot papers. Julia Gillard's January announcement of a September election established a generous timetable for new party registration, and in the two months before the register was closed by the issue of writs, 19 new parties had registered. This was an increase of around 50 per cent since January and meant a record number of parties were registered and able to contest the 2013 election, as shown in Table 1.

Table 1: Number of registered parties at Australian elections 1984-2013

\begin{tabular}{|l|r|r|r|}
\hline Election & Number registered & Contesting House & Contesting Senate \\
\hline 1984 & 18 & 11 & 13 \\
\hline 1987 & 23 & 12 & 16 \\
\hline 1990 & 32 & 22 & 20 \\
\hline 1993 & 27 & 16 & 22 \\
\hline 1996 & 28 & 18 & 23 \\
\hline 1998 & 41 & 25 & 30 \\
\hline 2001 & 38 & 22 & 29 \\
\hline 2004 & 34 & 26 & 30 \\
\hline 2007 & 27 & 19 & 26 \\
\hline 2010 & 25 & 22 & 25 \\
\hline 2013 & 54 & 34 & 51 \\
\hline
\end{tabular}

Source: Compiled from party registration data on AEC website and from past election results. Separate state Green parties at elections before 2001 have been counted as a single party.

A total of 1,188 candidates were nominated for the 150 House contests, more than the previous record of 1,109 candidates for 148 seats in 1998. This was an increase from 859 House candidates in 2010, much of this due to new parties. The newly formed Palmer United Party contested all 150 electorates, Katter's Australia Party 63 and the Rise Up Australia Party 77.

The increase in Senate candidates was more dramatic, a total of 529 candidates nominating, well up on the previous record of 367 in 2007. Record numbers of candidates contested every state. The New South Wales Senate ballot paper had 110 candidates and 45 columns on a ballot paper one metre wide, with column widths reduced to two centimetres and font size to six points. In the larger states the AEC made magnifying sheets available to assist voters in reading their ballot papers. Between 1949 and 1987 more than half of House electorates had been contested by four or fewer candidates, whereas in 2013 more than 
half had eight or more and a general election record of 16 candidates contested Melbourne. Table 2 shows the average number of candidates per vacancy at House and Senate elections since 1974.

Table 2: Average number of candidates per vacancy, Australian elections 1974-2013

\begin{tabular}{|l|r|r|r|r|r|}
\hline Election & \multicolumn{1}{|l|}{ House } & \multicolumn{1}{l|}{ Senate } & \multicolumn{1}{l|}{ Election } & House & Senate \\
\hline 1974 & 3.9 & 4.1 & 1993 & 6.4 & 6.7 \\
\hline 1975 & 3.8 & 4.2 & 1996 & 6.1 & 6.4 \\
\hline 1977 & 4.1 & 4.4 & 1998 & 7.5 & 8.2 \\
\hline 1980 & 4.0 & 5.4 & 2001 & 6.9 & 7.1 \\
\hline 1983 & 4.2 & 3.8 & 2004 & 7.3 & 8.3 \\
\hline 1984 & 4.2 & 4.4 & 2007 & 7.0 & 9.2 \\
\hline 1987 & 4.1 & 3.4 & 2010 & 5.7 & 8.7 \\
\hline 1990 & 5.3 & 5.6 & 2013 & 7.9 & 13.2 \\
\hline
\end{tabular}

Source: Calculated from published Australian Electoral Commission statistics.

Full preferential voting for House elections requires that all squares on the ballot paper be correctly numbered. Past research has shown that the rate of informal voting increases with the number of candidates, rates of informal voting also being higher in electorates with high concentrations of voters born overseas and speaking a language other than English at home. Confusion also arises with the ' 1 ' only ticket voting option allowed on Senate ballot papers, and with the use of optional preferential voting for state elections in New South Wales and Queensland (Australian Electoral Commission 2011).

Informal voting in the House of Representatives rose from 5.5 per cent in 2010 to 5.9 per cent in 2013, with New South Wales recording the highest rate at 7.6 per cent as well as the largest increase. Research on the 2013 informal vote is not yet available, but its geographic pattern was similar to that recorded in 2010, being highest in high migrant and non-English speaking parts of western Sydney, above 13 per cent in the electorates of Blaxland, Chifley, Fowler and Watson, and passing 20 per cent in individual polling places.

\section{Two-party-preferred results and swings}

The Coalition won the 2013 election with 53.5 per cent of the national twoparty-preferred vote, an overall swing of 3.6 percentage points with all states and territories swinging to the Coalition. The Coalition recorded two-partypreferred majorities in four states and the Northern Territory, Labor the majority party in the Australian Capital Territory, Victoria and Tasmania. 
The historic scale of the Coalition victory varied. In Victoria, Queensland and South Australia, the Coalition's two-party-preferred vote was down on John Howard's final victory in 2004. The Coalition recorded its highest two-partypreferred vote in Tasmania since 1990, in Western Australia since 1977, and New South Wales since the 1966 landslide. The Labor Party recorded its lowest proportion of seats in New South Wales since 1934.

The Coalition gained 17 seats from Labor as differential state swings delivered five seats more than would have been expected with a uniform national swing. The Nationals gained Lyne and New England from their retiring independent MPs, the Liberal Party lost Fairfax to the Palmer United Party and Indi to an independent, but gained O'Connor from the National Party. Of the 150 electorates, 137 recorded swings to the Coalition. Figure 1 shows the average swing in each state, the variance of the swing as well as swing outlier electorates in each state.

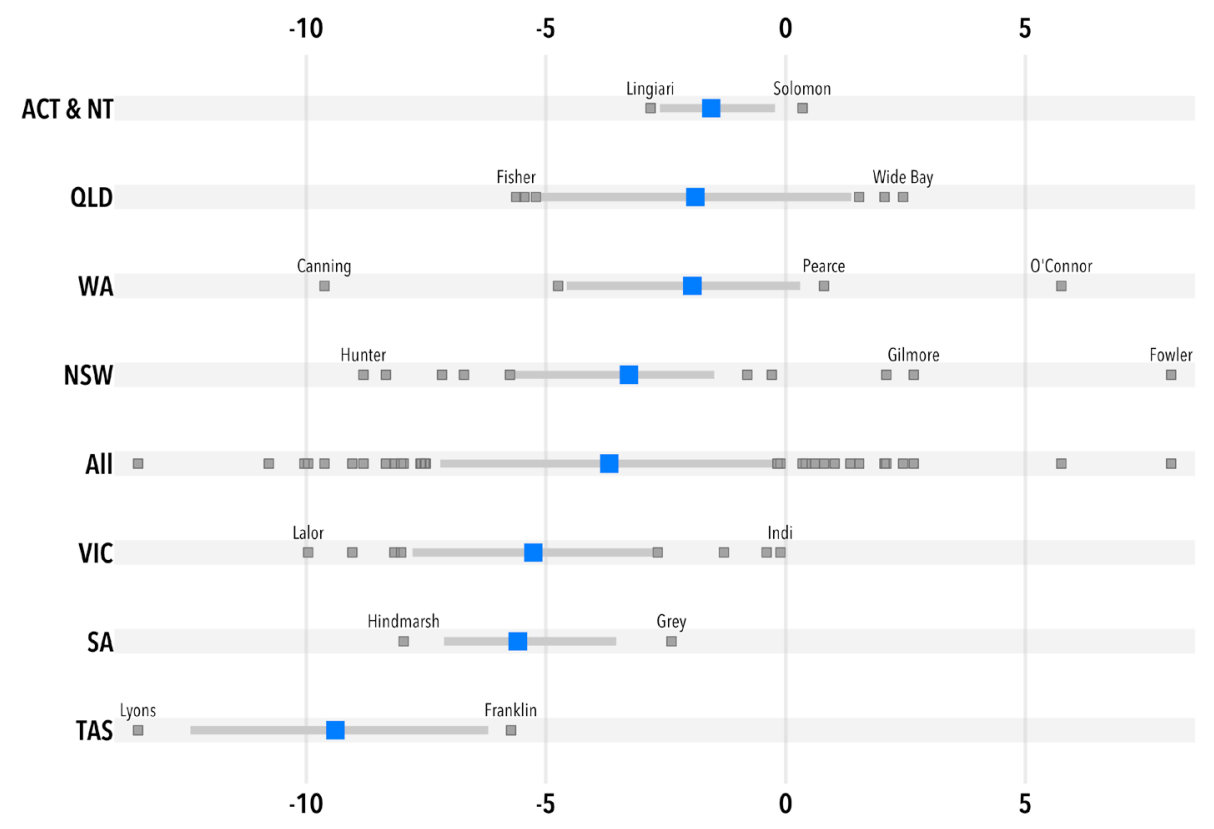

Figure 1: Average swing, swing variance and swing outlier electorates by state

Note: Lines cover 10th to 90th percentiles; blue squares are means.

Source: Data from the Australian Electoral Commission; computed and graphed by Simon Jackman.

The election's three largest swings were in Tasmania, where an unpopular state Labor Government helped deliver Lyons (margin 12.3, swing 13.5), Braddon 
(margin 7.5, swing 10.0), and Bass (margin 6.7, swing 10.8) to the Liberal Party. Of the 13 seats that swung to Labor, seven were in Queensland, a state where the return of Kevin Rudd and the rise of the Palmer United Party may have combined to ameliorate the swing predicted by polling earlier in the year. Labor lost only one seat in South Australia and three in Victoria despite state-wide swings of more than 5 percentage points.

In 2010 Labor had won a majority of New South Wales seats with a minority of the two-party-preferred vote. The 2013 results corrected the ledger, with the Coalition gaining 10 seats, eight from Labor plus the former independent seats of Lyne and New England. Despite predictions of a dire Labor result in western Sydney, only the bellwether electorate of Lindsay was lost, while Greenway was retained with a swing towards Labor thanks to the problems of the hapless Liberal candidate Jaymes Diaz. Labor lost the inner Sydney seats of Banks and Reid for the first time ever, and Barton for the first time since 1983.

The divergence from any uniform swing is explained by the overall pattern of state swings. As shown in Table 3, the swings against Labor in 2013 were largest in the states that had swung to Labor in 2010, and smallest in the states where there had been large anti-Labor swings in 2010.

Table 3: Two-party-preferred swings by state 2007-13

\begin{tabular}{|l|r|r|r|}
\hline Category & Swing 2007-10 & Swing 2010-13 & Swing 2007-13 \\
\hline NSW & -4.9 & -3.2 & -8.1 \\
\hline Vic & +1.0 & -5.1 & -4.1 \\
\hline Qld & -5.5 & -1.9 & -7.4 \\
\hline WA & -3.1 & -1.9 & -5.0 \\
\hline SA & +0.8 & -5.6 & -4.8 \\
\hline Tas & +4.4 & -9.4 & -5.0 \\
\hline ACT & -1.7 & -1.8 & -3.5 \\
\hline NT & -4.7 & -1.0 & -5.7 \\
\hline National & -2.6 & -3.6 & -6.2 \\
\hline Range of swings & 9.9 & 8.4 & 4.6 \\
\hline
\end{tabular}

Note: ' + ' indicates a swing to Labor, '-' a swing away from Labor and to the Coalition.

Source: Calculated from published Australian Electoral Commission statistics.

The final row of Table 3 shows the range of state swings at the 2010 and 2013 elections, much larger than recorded at recent elections, 5.5 percentage points in 2007, 3.6 in 2004, 3.2 in 2001 and 3.9 in 1998. The smaller range of swings over two elections in the final column points to Labor's defeat in 2013 being a levelling out of the swing over two elections. The 2010 swing laggards caught up with the mood of the nation in 2013. 
Changing party fortunes in New South Wales and Victoria were an important dynamic of both the 2010 and 2013 elections. Victoria was once 'the jewel in the Liberal crown', but the state is increasingly a stronghold for Labor. Labor has recorded a majority of the two-party-preferred vote in Victoria at 11 of the 13 elections since 1980, a better record for Labor than any other state. Victoria was also the only state to deliver a majority of seats for Labor in 2013, whereas in New South Wales Labor recorded its lowest proportion of seats since 1934. Labor's two-party-preferred percentage was higher in New South Wales than Victoria at every election from 1954 to 1977, but since 1980 it has been Victoria with the higher Labor two-party-preferred vote at 11 of the last 13 elections.

Between the 2010 and 2013 federal elections, Labor lost local office in both states. In Victoria the Coalition's victory was narrow and unexpected, and the new Government has since struggled in opinion polls. In New South Wales the Coalition won the 2011 state election with the biggest landslide in the state's history and opinion polls have indicated little resurgence in support for the once dominant New South Wales Labor Party. At both state and federal levels, it appears the Labor Party's historical weakness in Victoria is over, while in New South Wales the Coalition has improved its electoral performance in what was once a Labor-leaning state.

\section{Changing first preference vote share and analysis of preference flows}

Table 4: Change in first preference vote and two-party swing by state 2007-13

\begin{tabular}{|l|r|r|r|r|r|}
\hline Category & \multicolumn{1}{|l|}{ Labor } & \multicolumn{1}{|l|}{ Coalition } & \multicolumn{1}{|l|}{ Greens } & 2PP Swing \\
\hline NSW & -9.6 & +6.8 & - & +2.8 & 8.1 to Coalition \\
\hline Vic & -9.9 & +1.6 & +2.6 & +5.7 & 4.1 to Coalition \\
\hline Qld & -13.1 & +1.2 & +0.6 & +11.3 & 7.4 to Coalition \\
\hline WA & -8.0 & +3.8 & +0.8 & +3.4 & 5.0 to Coalition \\
\hline SA & -7.5 & +2.7 & +1.4 & +3.4 & 4.8 to Coalition \\
\hline Tas & -8.0 & +2.1 & -5.2 & +11.1 & 5.0 to Coalition \\
\hline ACT & -8.2 & +1.4 & +0.2 & +6.6 & 3.5 to Coalition \\
\hline NT & -10.2 & +3.5 & -0.1 & +6.8 & 5.7 to Coalition \\
\hline National & -10.0 & +3.5 & +0.8 & +5.7 & 6.2 to Coalition \\
\hline
\end{tabular}

Source: Calculated from published Australian Electoral Commission statistics.

Table 4 sets out the change in first preference vote over the two terms of the Labor Government. Labor lost more than 7.5 percentage points of vote share 
in every state and territory, but only in New South Wales did more than half of this re-appear as a lift in Coalition vote share. In most states the two-partypreferred swing against Labor was substantially smaller than its loss of first preference share, the two-party-preferred swing against Labor ameliorated by the flow back of preferences from an increased pool of votes for minor parties and independents.

The rise in support for non-major party candidates is shown clearly in Figure 2. Support for non-major alternatives passed 10 per cent at only four elections between 1949 and 1987,7 but has been above 10 per cent at every election since 1990, reaching highpoints of 17.1 per cent in 1990, 20.4 per cent at One Nation's first election in 1998, and a record 21.1 per cent in 2013. As Figure 2 shows, minor party and independent voting has been consistently higher in the Senate, reaching 32.2 per cent in 2013.

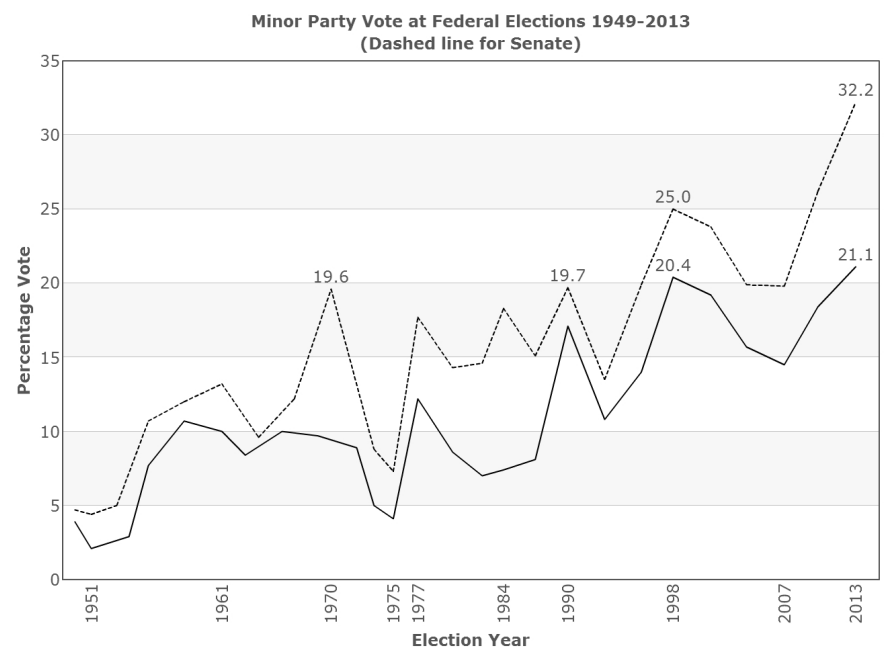

Figure 2: Minor party vote at federal elections, 1949-2013

Source: Author's work, from Australian Electoral Commission data.

The rise in support for non-major party candidates has been at the expense of Labor rather than the Coalition. The first preference vote share of both Labor and the Coalition was above 40 per cent at every election from 1949 to 1987. Since 1990, the only election where the Coalition vote share failed to reach 40 per cent was One Nation's first contest in 1998, while Labor has been below

7 Three times in the heyday of the DLP $(1958,1961,1966)$ and a then record 12.2 per cent at the Australian Democrats' first election in 1977. 
40 per cent at six of the past nine elections. The 1987 election was the first national victory by Labor with a lower first preference vote share than the Coalition, a feat since repeated in 1990 and 2010.

While Labor has been losing vote share to minor parties and independents, it has been attracting an increasing proportion of these votes back as preferences. The availability of accurate two-party-preferred counts since 1983 makes it possible to analyse the overall direction of distributed preferences. Table 5 provides two estimates of this. The second and third columns estimate the overall proportion of distributed preferences that flowed to Labor and the Coalition. The fourth and fifth columns show the percentage of the two-party-preferred vote for Labor and the Coalition that was derived as second and higher preferences rather than first preferences.

\section{Table 5: Split of national preferences House of Representatives elections} 1984-2013

\begin{tabular}{|l|r|r|r|r|}
\hline Election & $\begin{array}{l}\text { \% preferences to } \\
\text { Labor }\end{array}$ & $\begin{array}{l}\text { \% preferences to } \\
\text { Coalition }\end{array}$ & $\begin{array}{l}\text { \% Labor 2PP from } \\
\text { preferences }\end{array}$ & $\begin{array}{l}\text { \% Coalition 2PP from } \\
\text { preferences }\end{array}$ \\
\hline 1983 & 54.3 & 45.7 & 7.0 & 6.8 \\
\hline 1984 & 56.7 & 43.3 & 8.2 & 6.7 \\
\hline 1987 & 61.8 & 38.2 & 9.8 & 6.3 \\
\hline 1990 & 61.2 & 38.8 & 21.0 & 13.3 \\
\hline 1993 & 60.3 & 39.7 & 12.7 & 8.8 \\
\hline 1996 & 54.4 & 45.6 & 16.4 & 11.9 \\
\hline 1998 & 53.4 & 46.6 & 21.3 & 19.4 \\
\hline 2001 & 58.5 & 41.5 & 22.9 & 15.6 \\
\hline 2004 & 61.5 & 38.5 & 20.4 & 11.4 \\
\hline 2007 & 64.1 & 35.9 & 17.7 & 11.0 \\
\hline 2010 & 66.0 & 34.0 & 24.2 & 12.6 \\
\hline 2013 & 62.3 & 37.7 & 28.2 & 14.8 \\
\hline
\end{tabular}

Source: Calculated from published AEC results.

Preferences for Labor in the tables may be inflated in the 1980s by the leakage of Coalition votes in triangular contests, but the number of such contests has fallen since $1990 .^{8}$ As Table 5 shows, Labor now consistently attracts more than 60 per cent of preferences from other candidates, the rate heavily influenced by strong preferences to Labor from the Greens since 2001. Using the final two columns, the election where the Coalition most relied on preferences was 1998, when 19.4 per cent of the Coalition's two-party-preferred vote came via

8 Triangular or three-cornered contests take place where both Coalition parties nominate candidates against Labor. There were 64 triangular contests in 1984, 72 in 1987 after the breakdown of the federal Coalition, but fewer than 20 at each election since 1996. There were 10 triangular contests at the 2013 election. 
preferences. Labor's reliance has been higher than this figure at six of the nine elections since 1990. In 2010 and 2013, preferences as a proportion of Labor's two-party-preferred were around twice that of the Coalition.

The change in preferences is reflected in Labor's increasing ability to win electorates after trailing on first preferences. Table 6 identifies the number of trailing candidate victories for all parties since 1949 without taking into account triangular contests.

Table 6: Electorates where preference distribution changed the result 1949-2013

\begin{tabular}{|c|c|c|c|c|}
\hline Election & $\%$ changed on preferences & Won by Labor & Won by Coalition & Won by others \\
\hline 1949 & 7.4 & 1 & 8 & - \\
\hline 1951 & 1.7 & 1 & 1 & - \\
\hline 1954 & 1.7 & - & 2 & - \\
\hline 1955 & 0.8 & - & 1 & - \\
\hline 1958 & 6.6 & - & 8 & - \\
\hline 1961 & 5.7 & 1 & 6 & - \\
\hline 1963 & 6.6 & - & 8 & - \\
\hline 1966 & 4.1 & - & 4 & 1 \\
\hline 1969 & 9.6 & - & 12 & - \\
\hline 1972 & 11.2 & - & 14 & - \\
\hline 1974 & 7.9 & 1 & 9 & - \\
\hline 1975 & 5.5 & - & 7 & - \\
\hline 1977 & 3.2 & - & 4 & - \\
\hline 1980 & 4.8 & 3 & 3 & - \\
\hline 1983 & 1.6 & - & 2 & - \\
\hline 1984 & 8.8 & - & 13 & - \\
\hline 1987 & 2.7 & - & 4 & - \\
\hline 1990 & 6.8 & 7 & 3 & - \\
\hline 1993 & 8.2 & 4 & 6 & 2 \\
\hline 1996 & 4.7 & 2 & 4 & 1 \\
\hline 1998 & 4.7 & 4 & 3 & - \\
\hline 2001 & 4.0 & 4 & 2 & - \\
\hline 2004 & 5.3 & 8 & - & - \\
\hline 2007 & 6.0 & 9 & - & - \\
\hline 2010 & 9.3 & 8 & 4 & 2 \\
\hline 2013 & 10.0 & 12 & - & 3 \\
\hline
\end{tabular}

Source: Re-calculated from election results, based on Rydon (1986), Hughes (1997) and Bean (1997).

The trend to Labor winning from behind is even starker if the figures in Table 6 are adjusted to take account of triangular contests. Between 1955 and 1972 at the 
highpoint of the breakaway Democratic Labor Party, Labor won only three seats after trailing the combined Coalition first preference vote, whereas the Coalition won 36 victories after trailing Labor. Since 1990 a very different picture has emerged, with Labor winning 71 contests after trailing the combined Coalition first preference vote, compared to just two such trailing victories for the Coalition. Labor won eight seats from second place at the 2010 election, making it one of the few elections where preferential voting would have changed the overall outcome. Labor would also have lost had optional preferential voting been used (Green 2013a).

In 2013 the Coalition won 46 seats with a first preference majority compared to Labor's seven. The Coalition won a further 44 seats after leading on first preferences, Labor won 36 and others two. Labor won 12 seats in come-frombehind victories, almost one in four of its elected members and more seats than it won on first preferences. Labor closed first preference gaps ranging from 1.1 to 9.3 percentage points. Three crossbench members were elected from second place on strong flows of Labor and Green preferences, with Clive Palmer closing a 14.8 percentage point gap to defeat his Liberal-National opponent in Fairfax.

Since 1996, the AEC has published 'preference flow' data, tallies of the twoparty-preferred destination of ballot papers for excluded candidates, without the intermediary exclusions in traditional preference distribution tables. Table 7 extracts the preference flow data for significant parties at all elections since 1996. The table shows the very strong flows of preferences to Labor from the Greens, increasingly strong flows of Australian Democrat preferences to Labor in that party's latter years as a significant force, and the more evenly divided preferences of Coalition-leaning minor parties.

Table 7: Preference flows from significant minor parties to major parties 1996-2013

\begin{tabular}{|c|c|c|c|c|}
\hline Party & Election & $\%$ first preferences & $\begin{array}{l}\% \text { preferences } \\
\text { to Labor }\end{array}$ & $\begin{array}{l}\% \text { preferences } \\
\text { to Coalition }\end{array}$ \\
\hline \multirow[t]{4}{*}{ Australian Democrats } & 1996 & 6.8 & 54.0 & 46.0 \\
\hline & 1998 & 5.1 & 56.7 & 43.3 \\
\hline & 2001 & 5.4 & 64.1 & 35.9 \\
\hline & 2004 & 1.2 & 59.0 & 41.0 \\
\hline \multirow[t]{7}{*}{ Greens } & 1996 & 2.9 & 67.1 & 32.9 \\
\hline & 1998 & 2.6 & 73.3 & 26.7 \\
\hline & 2001 & 5.0 & 74.8 & 25.2 \\
\hline & 2004 & 7.2 & 80.9 & 19.1 \\
\hline & 2007 & 7.8 & 79.7 & 20.3 \\
\hline & 2010 & 11.8 & 78.8 & 21.2 \\
\hline & 2013 & 8.6 & 83.0 & 17.0 \\
\hline
\end{tabular}


Abbott's Gambit: The 2013 Australian Federal Election

\begin{tabular}{|c|c|c|c|c|}
\hline Party & Election & $\%$ first preferences & $\begin{array}{l}\% \text { preferences } \\
\text { to Labor }\end{array}$ & $\begin{array}{l}\% \text { preferences } \\
\text { to Coalition }\end{array}$ \\
\hline \multirow[t]{3}{*}{ One Nation } & 1998 & 8.4 & 46.3 & 53.7 \\
\hline & 2001 & 4.3 & 44.1 & 55.9 \\
\hline & 2004 & 1.2 & 43.8 & 56.2 \\
\hline \multirow[t]{4}{*}{ Family First } & 2004 & 2.0 & 33.3 & 66.7 \\
\hline & 2007 & 2.0 & 39.7 & 60.3 \\
\hline & 2010 & 2.3 & 40.2 & 59.8 \\
\hline & 2013 & 1.4 & 41.7 & 58.3 \\
\hline Palmer United Party & 2013 & 5.5 & 46.3 & 53.7 \\
\hline
\end{tabular}

Note: Totals for 1996-2004 exclude a small number of electorates that did not finish as Labor-Coalition contests.

Source: Calculated from AEC preference flow data.

In the 139 electorates where preference flow data is available for the 2013 election, Green flows to Labor ranged from 58.0 per cent to 91.1 per cent. The flow was greater than 70 per cent in 135 electorates, greater than 80 per cent in 85 electorates, and greater than 85 per cent in 36 electorates.

By actively distributing how-to-vote material outside polling places and recommending preferences to Labor, there should be a relationship between a higher Green first preference vote and higher flows of preferences to Labor. The electorate level preferences show that the higher the Green vote, the stronger the flow of preferences to Labor. When the Greens experimented with issuing open how-to-vote material with no recommendation of preferences in 2010, the flow of preferences to Labor was weaker by three percentage points on average where open tickets were issued (Green 2011).

The 2013 election's new entrant, the Palmer United Party (PUP), displayed weaker flows of preferences. Despite its how-to-vote material recommending preferences to the Coalition in every electorate, only 53.7 per cent of PUP voters followed the recommendation. Preferences favoured Labor in 43 electorates and the Coalition 96. Preference flows to the Coalition ranged from 39.3 per cent in Labor-held Calwell, to 64.7 per cent in National-held Gippsland. There was only a weak relationship between the flow of preferences to the Coalition and the PUP first preference vote share.

Why was the flow of PUP preferences so different to the Greens? One possibility is that PUP distributed less how-to-vote material, though the lack of relationship between PUP's vote share and the flow of preferences suggests how-to-vote material may not have been a strong influence. Another possibility is that voters may make up their own minds. At the 2010 Victorian state election, the Victorian 
Electoral Commission undertook research on whether ballot papers exactly followed a party's how-to-vote recommendation. In three inner-Melbourne electorates where the Greens finished second ahead of the Liberal candidate, between 21.6 per cent and 27.4 per cent of ballot papers exactly matched the Green how-to-vote recommendation (Victorian Electoral Commission 2011:71). Examination of the distribution of preferences in these electorates reveals that more than 80 per cent of Green preferences reached the Labor candidate ahead of the Liberal, which suggests more than half of Green voters devised their own sequence of preferences to complete their ballot papers to achieve the same purpose.

The pattern of Green preferences, the party's ideology and the geographic and historic pattern of Green support suggest that the Greens draw overwhelmingly from left-aligned voters. Having voted Green, the pattern of preference flows suggest these electors give preferences back to Labor as being aligned with their personal ideology. The geographic distribution of PUP support provides fewer clues on the previous party allegiance of its supporters. The PUP's highest first preference vote share by state was 11.0 per cent in Queensland, the only state where the Coalition's first preference vote share declined at the 2013 election. It appears the PUP drew support from past supporters of both major parties. The lack of strong preference flows to the Coalition, despite PUP's recommendation, suggests many voters may have voted for PUP candidates and then directed preferences back to the party they traditionally supported. PUP may have provided an opportunity for voters to send a message to their traditional party without having to traverse the two-party political divide, especially in the case of traditional Labor voters.

One significant change in preference strategy at the 2013 election was made by the Coalition. At previous elections the Coalition recommended preferences for their 'enemy's enemy', putting the Greens ahead of Labor. In 2013, as part of a strategy to paint Labor as doing deals with the 'extremist' Greens, the Coalition reversed its position and recommended its lowest preferences to Labor ahead of the Greens. In 2010 Liberal preference flows had been 77.9 per cent to the Greens in the three electorates where its preferences counted, but in 2013 only 34.2 per cent flowed to the Greens in the three seats counted. In 2010, Liberal preferences lifted Greens' candidate Adam Bandt from second place to victory over Labor in Melbourne. Had the Liberal Party's 2013 preference strategy applied in 2010, Labor would never have lost Melbourne. In 2013, a first preference shift from Labor to the Greens in Melbourne nullified the change in Liberal preferences and Bandt was re-elected. 


\section{The strange contest for the Senate}

The use of preferential voting in single member House electorates may have protected Labor from the consequences of its low vote share in 2013, but no such protection was afforded by the Senate's proportional form of preferential voting.

\section{Table 8: Summary of 2013 Senate result}

\begin{tabular}{|l|r|r|r|r|}
\hline Party & Continuing Senators & New senators & Total & Change \\
\hline Liberal-National Coalition & 16 & 17 & 33 & -1 \\
\hline Labor Party & 13 & 12 & 25 & -6 \\
\hline Australian Greens & 6 & 4 & 10 & +1 \\
\hline Democratic Labour Party & 1 & - & 1 & - \\
\hline Palmer United Party & - & 3 & 3 & +3 \\
\hline Nick Xenophon Group & - & 1 & 1 & - \\
\hline Liberal Democratic Party & - & 1 & 1 & +1 \\
\hline Family First & - & 1 & 1 & +1 \\
\hline Motoring Enthusiasts Party & - & 1 & 1 & +1 \\
\hline
\end{tabular}

Note: These figures incorporate the result of the Western Australian Senate re-run in April 2014, at which the Palmer United Party won a third seat at the expense of the originally elected Australian Sports Party. Note that Senate changes apply from 1 July 2014.

Source: AEC data.

The Labor Party lost six Senate seats, one in each state, and was reduced to single seats in both Western Australia and South Australia. Whereas in the existing Senate Labor's 31 seats plus nine Greens gave them an absolute majority in the 76-seat chamber, the combined Labor and Greens numbers in the new Senate will be 35, short of the 38 votes required to block Abbott Government legislation. With new Senators taking their seats in July 2014, the balance of Senate power will generally be with eight Senators on an expanded crossbench.

The Coalition aim was to maximise its Senate numbers so it could legislate to meet its election commitments. Instead, confusion created by the record number of candidates and parties cost the Coalition one of its existing Senate seats (in Victoria) and prevented it from gaining one and possibly two extra seats. In New South Wales, the largely unknown Liberal Democrats (LDP) benefited from drawing the left-hand column on the ballot paper, creating confusion with the Coalition's group labelled 'Liberal and National' in the 25th column. ${ }^{9}$ The LDP

9 Comparing New South Wales Coalition support in the House and Senate suggests voters were confused. The Coalition's first preference vote in the House rose 2.7 percentage points but fell 4.8 in the Senate. The gap between Coalition support in the two chambers was a record 13.1 percentage points. The Coalition recording its highest House vote share since 1975 but its lowest in the Senate since 1943. 
polled 9.5 per cent, triple its support in other states. Successful LDP candidate David Leyonhjelm won his seat at the expense of Labor, blocking the Greens who had won the equivalent seat in 2010.

The Greens recorded their highest Senate vote in 2013 in Victoria and took Labor's third seat. The surprise Victorian result was the defeat of third-placed Liberal Senator Helen Kroger by Ricky Muir of the Australian Motoring Enthusiasts Party (AMEP). The Coalition led the field with 40.1 per cent of the vote or 2.81 quotas against the 13th-placed Motoring Enthusiasts with 0.5 per cent or 0.04 quotas. Muir was elected through the extraordinary preference deals arranged by the micro party alliance (see below).

In both Queensland and Tasmania Labor lost its third Senate seat to the PUP. The Liberal Party had expected to gain a third Tasmanian seat, but minor party preferences delivered the final seat to the PUP. Green Senator Peter Whish-Wilson was re-elected, but with the lowest Tasmanian Green Senate vote since 1998.

The popularity of independent Senator Nick Xenophon complicated the South Australian Senate race. Xenophon's group nearly doubled its vote, polling 24.9 per cent - the highest vote ever recorded for a Senate independent - and pushing Labor into third place. With 1.74 quotas Xenophon's vote would have elected his second candidate Stirling Griff, except that Labor and the Greens chose to put Family First ahead of Griff on their preference tickets. Labor lost its second Senate seat by attracting only 22.7 per cent of the vote, but helped elect Family First's Bob Day. ${ }^{10}$

The Western Australian Senate produced the most remarkable result. Initially, Greens' Senator Scott Ludlam was defeated, losing his seat to the PUP's Zhenya Wang. As explained below, the closeness of the count at a key point resulted in a re-count at which Ludlam was re-instated in place of Wang. More remarkably, Labor's second Senator Louise Pratt was defeated, losing her seat to the Australian Sports Party's Wayne Dropulich. This was despite Labor polling 26.6 per cent or 1.86 quotas compared to just 0.23 per cent or 0.016 quotas for the Sports Party. The Sports Party finished 21st of the 27 parties on the ballot paper. Twenty different parties contributed votes through preference tickets to the party's victory, with 15 of those parties having recorded a higher share of the vote. At three points during the distribution of preferences Mr Dropulich had the second lowest vote tally of remaining candidates, only to survive by gaining ticket preferences on the exclusion of the only candidate with fewer votes (Green 2013b).

10 Labor right faction power broker Don Farrell had originally been chosen to lead the Labor ticket, but stood aside to let Finance Minister Penny Wong lead the ticket. That gesture plus Labor's low vote cost him his seat. 
The extraordinarily complex nature of the count and the determining power of ticket preferences were revealed by a 'choke point' in the count that determined the final two seats. At a point where only 10 candidates remained in the count, the two lowest polling candidates were from the Australian Christians and the Shooters and Fishers Party. Both had 1.8 per cent of the vote at this point, and on the first completed count, the Shooters and Fishers led the Australian Christians by 14 votes, resulting in the final two seats being won by Labor and the PUP. This 'choke point' was so close that the AEC ordered a re-count. During the recount, it was determined that 1,370 ballot papers included in the initial count could not be located. The distribution of preferences on this second count saw the Australian Christians finish 12 votes ahead of the Shooters and Fishers at the critical count, resulting in Dropulich and the Greens winning the final two seats. If the missing ballots were included based on their first count totals, then the Shooters and Fishers would have finished one vote ahead of the Australian Christians, resulting in Labor and PUP winning the final two seats. The AEC referred the count to the Court of Disputed Returns and a fresh election was ordered for the Western Australian Senate, at which the Liberal Party retained its three seats, Labor again failed to win a second seat, and the PUP and the Greens made up the complement.

The giant ballot papers and strange preference deals were a deliberate strategy by minor and 'micro' parties to try and win election to the Senate. One of the participants in this was the Australian Sex Party, whose registered officer and Tasmanian Senate candidate Robbie Swan (2013) described the process as follows:

Formed in Sydney by the man known as 'the preference whisperer', Glenn Druery, the Minor Party Alliance allowed minor and micro parties the chance to win a Senate seat off the back of a small primary vote, as long as all the parties in the Alliance preferenced themselves above the three major parties. ${ }^{11}$ It was a plan that most small parties wanted to be in on but it also required them to place some parties above others, which may not have reflected their own core values.

Would your party's stated policies and philosophies be more advanced by getting you elected, even though that may come at the risk of supporting another small party with an opposing political outlook? That was the question.

11 Note that Swan is here including the Greens as a major party. 
The Pirate Party and the Secular Party did not join the group. Animal Justice, Australian Independents, HEMP and the Democrats were all committed. Wikileaks were players who made a couple of genuine administrative errors in their final preferences.

The Sex Party were open about having one foot in the Alliance and one foot out. This hokey-pokey, each way bet approach was the one that I supported. The Sex Party refused to preference the religious right anywhere but at the very bottom of our ticket. For this we were penalised within the Alliance and yet still allowed to stay, because we preferenced mostly progressive small parties at the top and were considered to be one of the major minor parties that delivered a substantial primary vote.

With the Minor Party Alliance running across the political spectrum from the left-libertarian Sex Party to the various conservative Christian parties, parties that sat to the political centre of this grouping were the main beneficiaries. The success of the Motoring Enthusiasts in Victoria, the PUP in Tasmania (and initially the Sports Party in Western Australia) and to a lesser extent the Liberal Democrats in New South Wales, stems from this tactic by the minor party participants to manipulate group ticket voting to accumulate votes within the alliance and win seats ahead of the Greens and the major parties. In 1984, with the Nuclear Disarmament Party, and in 1998 with Pauline Hanson's One Nation, the larger parties used preference tickets to deny those new parties entry to the Senate. In 2013, the Minor Party Alliance used the same rules to engineer victory by participants in the alliance. The Minor Party Alliance 'gamed' the system, but they did no more than use the rules as they existed and as they had been used by the major parties in the past.

However, the election of two unknown candidates with extremely low vote shares via labyrinthine preference tickets built on strategy rather than ideology has raised serious questions about the Senate's electoral system as well as the rules governing the registration of political parties. Changing the rules will be a challenge for the Abbott Government given that its ability to legislate on all other matters will depend on a Senate crossbench elected under the existing rules.

\section{References}

Australian Electoral Commission (AEC). 2011. Analysis of Informal Voting, House of Representatives, 2010 federal election. Research Report Number 12, 29 March. 
Barber, Stephen. 2011. Federal Election Results 1901-2010. Parliamentary Library Research Paper No. 6, 2011-12, Canberra: Parliament of Australia.

Bean, Clive. 1997. 'Australia's Experience with the Alternative Vote'. Representation 34(2): 103-10.

Green, Antony. 2011. 'Does it Matter if the Greens do not Direct Preferences to Labor?' Antony Green's Election Blog, 7 November, viewed 14 January 2014: <blogs.abc.net.au/antonygreen/2011/11/does-it-matter-if-the-greens-donot-direct-preferences-to-labor.html $>$.

Green, Antony. 2013a. '2010 Federal Election-Would Optional Preferential Voting Have Changed the Result?' Antony Green's Election Blog, 10 January, viewed 14 January 2014: <blogs.abc.net.au/antonygreen/2013/01/2010federal-election-would-optional-preferential-voting-have-changed-theresult.html>.

Green, Antony. 2013b. 'The Remarkable Path to Victory of Wayne Dropulich'. Antony Green's Election Blog, 21 December, viewed 14 January 2014: <blogs. abc.net.au/antonygreen/2013/12/the-remarkable-path-to-victory-of-waynedropulich.html>.

Hughes, Colin A. 1990. 'Rules of the Game'. In Clive Bean, Ian McAllister and John Warhurst (eds), The Greening of Australian Politics: the 1990 Federal Election, Melbourne: Longman Cheshire.

Hughes, Colin A. 1997. 'Individual Electoral Districts'. In Clive Bean, Scott Bennett, Marian Simms and John Warhurst (eds), The Politics of Retribution: the 1996 Federal Election, Sydney: Allen \& Unwin.

Mackerras, Malcolm. 1990. 'Election Results'. In Clive Bean, Ian McAllister and John Warhurst (eds), The Greening of Australian Politics: the 1990 Federal Election, Melbourne: Longman Cheshire.

Rydon, Joan. 1986. A Federal Legislature: The Australian Commonwealth Parliament 1901-1980. Melbourne: Oxford University Press.

Swan, Robbie. 2013. 'The Greens Vs the Micro Party Alliance'. New Matilda, 17 October, viewed 14 January 2014: <www.newmatilda.com/2013/10/17/ greens-vs-micro-party-alliance $>$.

Victorian Electoral Commission. 2011. Report to Parliament on the 2010 Victorian State Election. Melbourne, August. 
This text taken from Abbott's Gambit: The 2013 Australian Federal Election, edited by Carol Johnson and John Wanna, published 2015 by ANU Press, The Australian National University, Canberra, Australia. 